\title{
Materials, used in historical buildings, analysis methods and solutions puroposals
}

\author{
M.Sami Döndüren ${ }^{1}$, and Ozlem Sişik $^{1}$ \\ ${ }^{1}$ Department of Civil Engineering, Selcuk University, 42060 Konya, Turkey
}

\begin{abstract}
Most of historical buildings are built with pressure principle and have the characteristics of masonry structures. Therefore, the structure components of buildings are constituted bearing walls, columns, buttresses, vaults and domes. Natural stone, cut stone, rubble stone brick or alternate materials were used in the bearing elements. Brick-dust and mortar with more binding feature were used as combination elements. In time, some problems were occurred in used materials and in structure as a result of various effects. Therefore, it is necessary to apply various applications in framework of repair and strengthening of buildings. In this study, restoration of historic buildings and the control of the adequacy of the bearing systems as one most important part of structure were examined. For this purpose, static analysis of Edirne-Merkez Demirtaş (Timurtaş) mosque located in Edirne was tested. Testes could give suggestions and be applied if buildings needed be revealed. The structure was modelled with finite element model of sap2000 package program and the forces generated under various loads and stresses, the occurred deformation due to that, overflow of allowable stress of this deformation and stresses were investigated. As the results of this study can be note that the maximum compressive stress at the construction is calculated as $1.1 \mathrm{MPa}$.
\end{abstract}

\section{Introduction}

Historical buildings are the most important ruins to describe history of a society. Buildings exposed to harsh effects of years and to natural disasters are generally under effect of very serious problems and they have risk of collapse and extinction. Historic buildings, which are the most important parts of our cultural heritage, must be best protected and repaired [1].

Most of historical buildings are built with pressure stress and have the characteristics of masonry structures. Therefore, the structure components of buildings are constituted bearing walls, columns, buttresses, vaults and domes [2]. Natural stone, cut stone, rubble stone brick or alternate materials were used in the bearing elements. Brick-dust and mortar with more binding feature were used as combination elements. The tensile forces of historical buildings have been met by using with wood elements or steel clamp, steel tensioner elements [3].

\section{Materials and Characteristics Used in Historical Buildings}

The building materials play a decisive role in the behaviors of the structures they use. Historical agglomerations use different materials such as natural stone, brick, wood, mortar. Understanding the physical and mechanical properties of these materials is an indispensable part of the work to be done to evaluate historical structures [4-6,7].

\section{Static Estimation of Historical Constructions}

\subsection{The Parameters Used In The Models For Structural Analysis}

Interpretation of the results of structural analyzes of historic buildings using the finite element method differences from the interpretation of the calculations of structures produced by today's engineering technologies. Because of it is not always possible to carry out experiments that will determine material properties by taking samples from historical structures, it is sometimes very difficult to determine the bearing capacities of structural members according to the calculation results.

The parameters used in the calculation of the structural earthquake forces are given below:

- A0 (Earthquake Region Coefficient) $=0.1$ (Region 4) 
- If the ground class is not foreseen, is taken according to DBYBHY S $(\mathrm{T})=2.5$

- $\quad$ I (Structure Importance Coefficient $)=1.0$

- $\mathrm{R}$ (Carrier System Behavior Coefficient $)=2$

In describing the masonry wall material, the Elasticity Module of the masonry units used for wall construction according to the directive is 200 times the character pressure resistance of the material,so;

$\mathrm{Ed}=200 * \mathrm{fd}$.

According to TS 2510 (Turkish Standarts 2510), the pressure resistance of natural stones used in construction of bearing walls should not be smaller than $350 \mathrm{kgf} / \mathrm{cm}^{2}$.

$f_{\mathrm{d}}=$ free pressure resistance $* 0.5$

$f_{\mathrm{d}}=0.5 * 350=175 \mathrm{~kg} / \mathrm{cm}^{2}$

$\mathrm{E}=f_{\mathrm{d}} * 200$

$\mathrm{E}=175 * 200=35000 \mathrm{~kg} / \mathrm{cm}^{2}$

The pressure safety tension for the stone masonry walls, $f_{\mathrm{em}}=0.3 \mathrm{MPa}$ is recommended.

Tension safety tensions can be accepted as $15 \%$ of the value determined as pressure safety tension. In this case, the tensile safety strain for the stone wall is calculated as $f_{m}=0.3 \times 0.15=0.045 \mathrm{MPa}$.

The earthquake force coming from the wall will be divided into the horizontal cross-sectional area of the wall to calculate the shear stress in the wall and to be compared with the wall slip safety stress $\tau_{\mathrm{em}}$, which will be denoted as Equation (3) [5].

$\tau_{\mathrm{em}}=\tau_{\mathrm{o}}+\mu \sigma$

$\tau_{\mathrm{em}}=0.10+0.5(0.3 / 2)=0.175 \mathrm{MPa}$

\subsection{Timurtaş (Demirtas) Mosque}

It is one of the earliest examples with a squareshaped, single-volume type of mosque. It is a monumental view with a monumental harim which is covered with Turkish triangles and sitting on a dodecagon pulley, and the architectural structure located on the northwest corner of it.

The Turkish triangles, which provide passage to the domes covering the Harimi, have been widely used in various forms in Turkish architecture. The building material was made of rubble stone,coarse stone and brick.

As an alternative wall technique was applied on the ground form walls with an alternate covering of a row of stones and two rows of bricks.

Brick material was used completely on bridges, belts, mihraptas and domes [3].

\subsubsection{Pre-restoration architectural featuresPre- restoration architectural features}

In this section informations given was taken from the restoration,pre- restoration and restoration reports prepared for the Timurtaş (Demirtaş) Mosque of Edirne foundation general in 2007 prior to restoration of the building. Figs. 1-3 show the pictures of the tomb before and after repair.

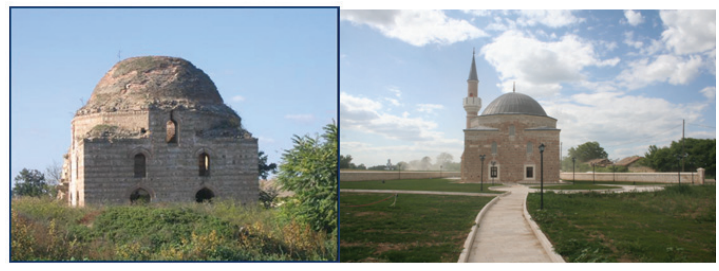

Fig. 1. Photographs before and after restoration of the Timurtaş(Demirtaş) Mosque (2007-2008).

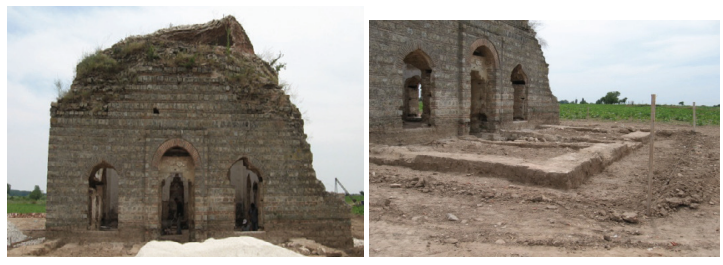

Fig. 2. Photographs before and after restoration of the Timurtaş(Demirtaş) Mosque (2007).
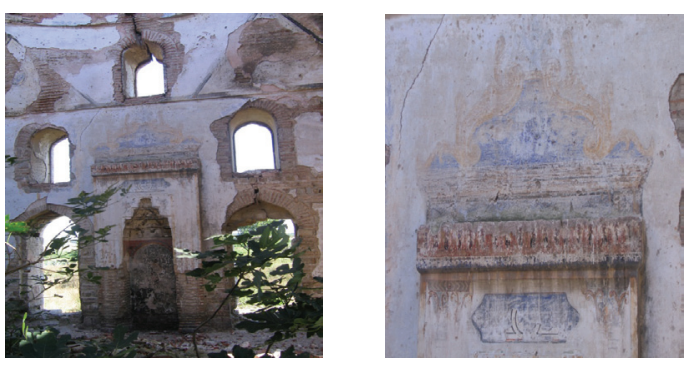

Fig. 3. Photographs before and after restoration of the Timurtaş(Demirtaş) Mosque (2007).

The material decrement on the groun form walls have been completed according to the original material and mesh system. Filling the capillary cracks in the structure with epoxy plaster, $4 \mathrm{~cm}$ wide cracks are stitched with iron plates and they are filled with epoxy again. For cracks larger than 4 $\mathrm{cm}$, it is recommended that the perimeter be disinfected and filled in accordance with the original material and mesh system. Except base of the minaret, the mosque was destroyed. Since the old photo about the minaret could not be found, it was completed with the guidance of periodical analyzes. As a suggested at the restitutions projects, the rostrum with alternated had been built of bricks. Transition from the ground form to the base was made with triangles. As a result of the periodical analyzes, this decision was made (Saruca Pasha 
Mosque, Bird's Dogan Mosque, Kadi Bedrettin Mosque). The height of the minaret was determined in proportion to the height of the dome as a result of the analysis. Minare Base height is determined from existing stone profiling. Minarets lug height is determined from the tracks in front again.

\subsubsection{Structural model and analysis}

SAP 2000 V18 finite element program is used for modeling. The building walls consist mainly of at least three main materials, stone, brick and mortar (plaster). However, since the general behavior of the structure in the model is concerned, it is assumed that the carrier elements are formed from a single material and the related unit volume weight, modulus of elasticity and Poisson's rate are used Sketches of the plan of the structure is given in Fig. 4.

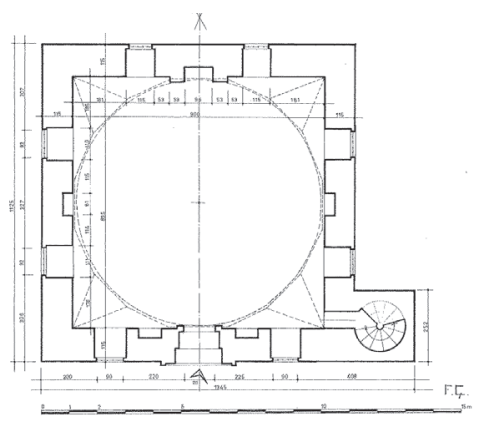

Fig. 4. Sketches of the plan of the Timurtaş (Demirtaş) Mosque.

Based on the build-up relay project, in the numerical model, the wall thickness is defined as $1.1 \mathrm{~m}$, and the thickness of the cove is defined as $0.25 \mathrm{~m}$. Material properties are defined; The material of the wall and minaret is stone, the material of the dome is brick. The carrier elements of the structure are modeled as shells. 559 shells (area) were created using 558 knot points in the prepared structure model. 51 fixed supports are defined in the points that are transferred to the ground. The structural modeling is given in Fig. 5 .
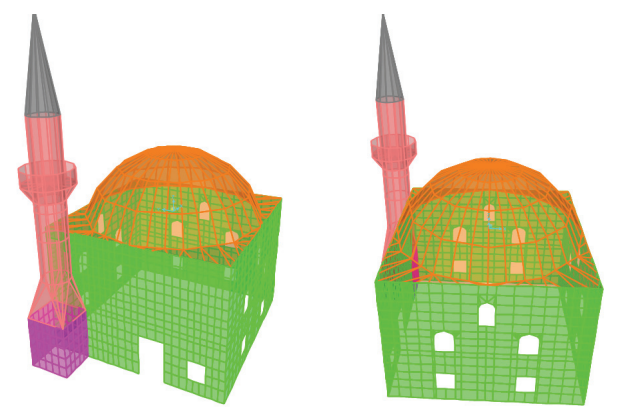

Fig. 5. Timurtaş (Demirtaş) Mosque structural modeling.

Since the results of the analysis obtained are very difficult to show for each knot and each element, the results obtained are presented in terms of colored stress distribution and graphs.

\subsubsection{The analysis of the structure under the dead load}

The weight effect of the structure is taken into account by using the values calculated in Unit volume weight $(\gamma)$, elasticity modulus (E) and Poisson ratio $(v)$ of building materials.

The weight of the structure is $\mathrm{G}=10351.5 \mathrm{kN}$.

As a result of the static analysis of the 3D final element model of Timurtaş (Demirtaş) Mosque under its own weight, the possible stress distributions in the structure, the strain values were reached and critical locations where cracks could occur were detected.

Under $\mathrm{G}$ force, the greatest displacement in the structure is about $0.979 \mathrm{~mm}$ in the vertical direction at the top of the dome. $\mathrm{R}=2$ is used in this analysis, the elastic displacement should be calculated as $0.979 \mathrm{~mm} \times 2=1.958 \mathrm{~mm}$ (Fig. 6). It is about $1.53 \mathrm{~mm}$ in the vertical direction at the top of Minaret. $\mathrm{R}=2$ is used in this analysis, the elastic displacement should be calculated as $1.53 \mathrm{~mm} \times 2$ $=3.06 \mathrm{~mm}$.
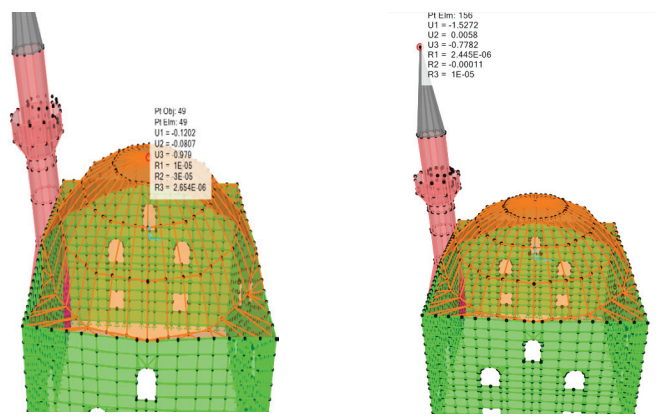

Fig. 6. Under $\mathrm{G}$ force, the greatest displacement in the Timurtaş (Demirtaş) Mosque (mm).

The behaviour of the structure according to the $\mathrm{G}$ force acting, prepared separately S22 and S11 (tensile and compressive) stress value graph (Fig. 7).

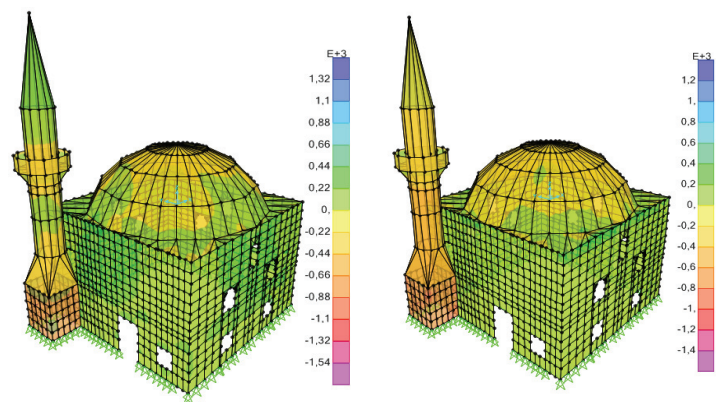

Fig. 7. Under G force, $\mathrm{S} 11$ and $\mathrm{S} 22$ Stresses in the Timurtaş (Demirtaş) Mosque $\left(\mathrm{KN} / \mathrm{m}^{2}\right)$. 


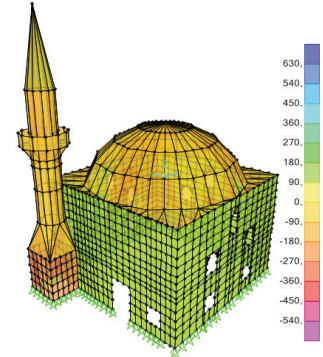

Fig. 8. Under G force, S12 Stresses in the Timurtaş (Demirtaş) Mosque $\left(\mathrm{KN} / \mathrm{m}^{2}\right)$.

The most unfavourable compressive stresses calculated were 1.54 MPa from S11 Graph and the most unfavorable tensile stresses were also found to be $1.32 \mathrm{MPa}$ on $\mathrm{S} 11$ graph (Fig. 8). However, it should be kept in mind that the values of the strain distributions in the graphs S11 and S22 are very close to one another. Both values exceed the safety stress values of the stone walls given in Table. The maximum shear strain determined from the $\mathrm{S} 12$ graph is $0.630 \mathrm{MPa}$. This value is also above the safe dislocation stress value.

As a results under $G$ force when the effects of structural analysis are examined, on the carrier walls of the structure. In the Turkish Earthquake Regulation, it has been observed that the compression tension and dislocation stress values proposed for masonry structures are exceeded. As a matter of fact, the size of the dome of the structure and the cracks formed is an indication that the structure is not stable (Fig. 9).
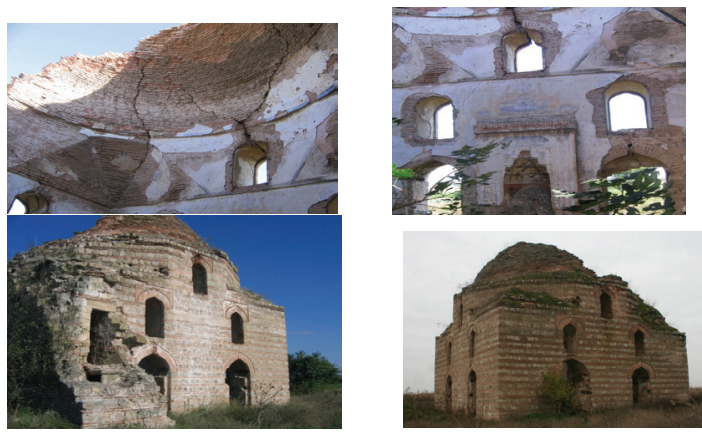

Fig. 9. Timurtaş (Demirtaş) Mosque prior to the restoration of damaged photos.

\subsubsection{Modal analysis}

The fixed spectral coefficient $\mathrm{S}(\mathrm{T})$ is assumed to be 2.5 and the effective earthquake coefficient Ao = 0.1 is assumed in the specular seismic solution. In defining the earthquake effects, the method of joining the modal effects is adopted and using the exact quadratic joining method. under the vertical structure and earthquake is intended to obtain the elastic behavior. The earthquake load reduction factor $\mathrm{R}=2$ is considered in all periods. Using modal analysis and mass and rigid matrices of the structure system. Mode shapes and periods are obtained.The mass participation rate of the fourth mode showing the lateral displacement movement of the main mass in the $\mathrm{X}$ direction is calculated as $54 \%$ and the mass participation rate of the third mode showing the lateral displacement movement in the $\mathrm{Y}$ direction is calculated $56 \%$. Since the structure is symmetrical, the mass participation rates give almost the same value. The highest natural vibration period already obtained is 0.24 and the building is very rigid.

In Fig. 10, the first 6 mode graphs of the structure are given.
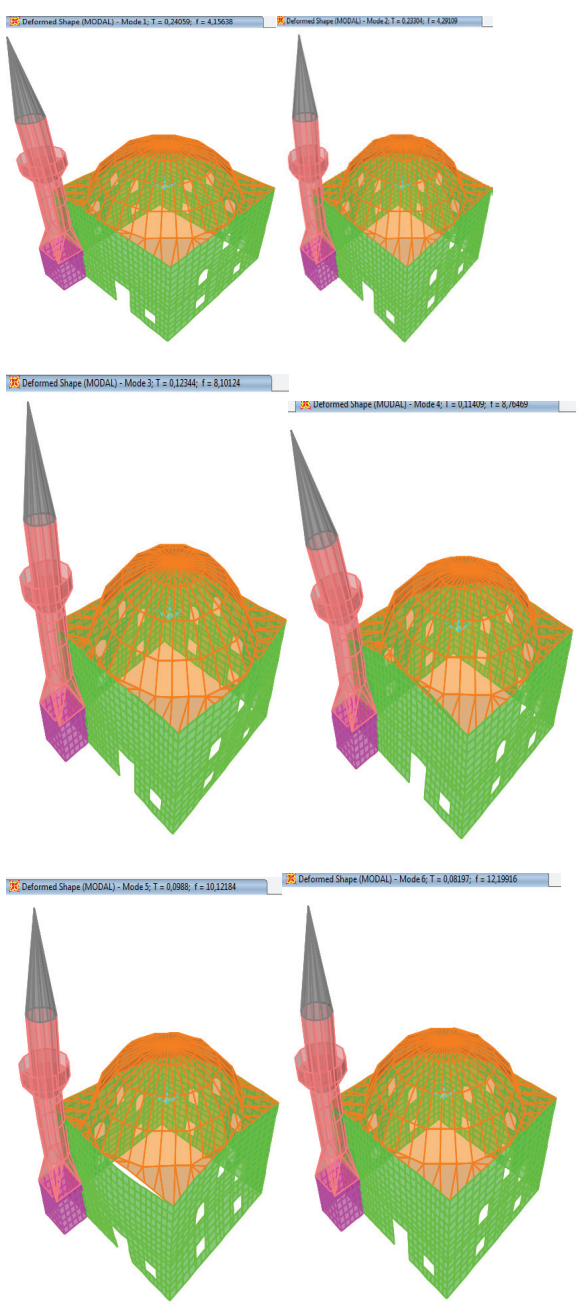

Fig. 10. The first 6 mode graphs of the Timurtas (Demirtaş) Mosque.

\subsubsection{G+Ex ve G+Ey earthquake loads}

Shape changes occurring in the modal spectral analysis resultant structure under earthquake load reduction $(\mathrm{R}=2)$ and earthquake loads acting in the direction of $\mathrm{X}$ and $\mathrm{Y}$ with dead load are given in Figs. 11 and 12 .

$\mathbf{G}+\mathbf{E}_{\mathbf{x}:}$ : The earthquake loading brings a lateral displacement of $12.75 \mathrm{~mm}$ in the $\mathrm{X}$ direction, 1.19 $\mathrm{mm}$ in the $\mathrm{Y}$ direction, $0.98 \mathrm{~mm}$ in the $\mathrm{Z}$ direction, 

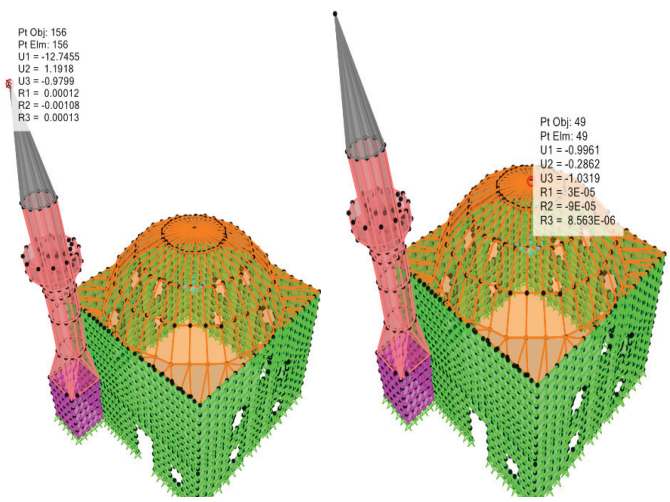

Fig. 11. Under $\mathrm{G}+\mathrm{E}_{\mathrm{x}}$ force, the greatest displacement in the Timurtaş (Demirtaş) Mosque (mm).

and $0.999 \mathrm{~mm}$ in the $\mathrm{X}$ direction and 0.29 in the $\mathrm{Y}$ direction and $1.03 \mathrm{~mm}$ in the $\mathrm{Z}$ direction.

$\mathbf{G}+\mathbf{E}_{\mathbf{y}}$ : The minaret in the $\mathrm{X}$ direction is 3.51 $\mathrm{mm}$ in the direction of the earthquake, $11.11 \mathrm{~mm}$ in the $\mathrm{Y}$ direction, $0.85 \mathrm{~mm}$ in the $\mathrm{Z}$ direction and $0.36 \mathrm{~mm}$ in the $\mathrm{X}$ direction, 1.19 in the $\mathrm{Y}$ direction and $1.08 \mathrm{~mm}$ in the $\mathrm{Z}$ direction.
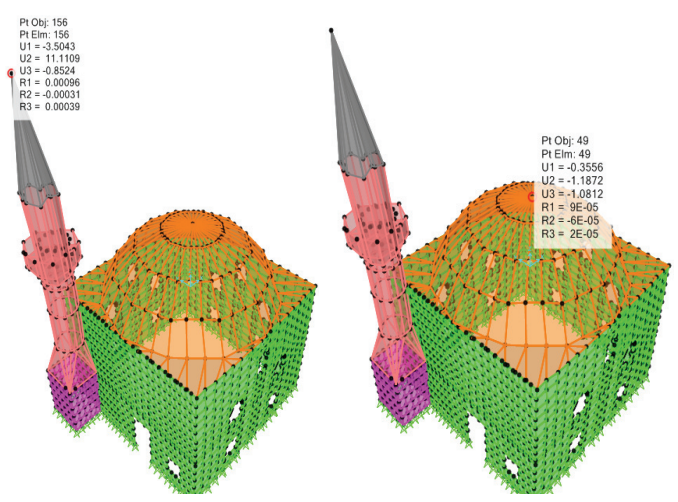

Fig. 12. Under $\mathrm{G}+\mathrm{E}_{\mathrm{y}}$ force, the greatest displacement in the Timurtaş (Demirtaş) Mosque (mm).

As a result of the analyzes made, it has been determined that the most difficult parts of the structure in the static state of the structure are the edges of the upper window cavities, the ground form that the dome and the dome 8,5 are sitting on.

$\mathbf{G}+\mathbf{E x}$ ve $\mathbf{G}+\mathbf{E}_{\mathbf{y}}$ : It is seen that in the case of earthquake loading, the regions, where the stresses of S11 (Fig. 13) and S22 (Fig. 14) in the structure are unfavorable there are at the corner points of the dome and wall joints and windows and door gaps. The greatest compressive stress in the structure is calculated as $1.1 \mathrm{MPa}$, which exceeds the pressure safety stress of $0.3 \mathrm{MPa}$. The tensile stresses determined at $2.16 \mathrm{MPa}$ in the construction exceed the tensile safety stress and reinforcement is require.

The calculated maximum displaced stresses were $\mathrm{G}+\mathrm{E}_{\mathrm{x}}$ ve $\mathrm{G}+\mathrm{E}_{\mathrm{y}}$ (Fig.15.) At $0.99 \mathrm{MPa}$. This value has exceeded the value of safe shear stress calculated as $0.175 \mathrm{MPa}$.
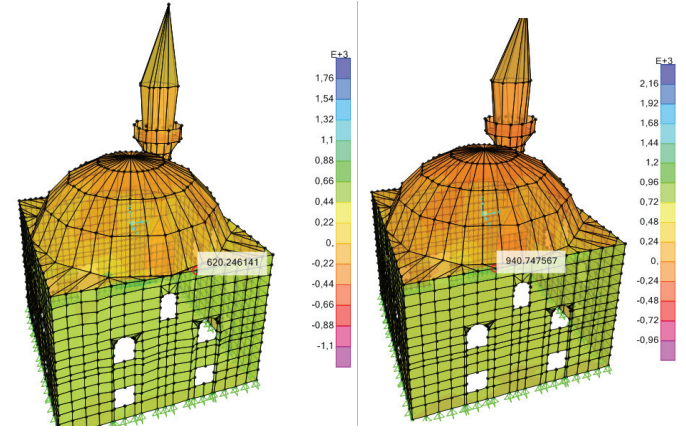

Fig. 13. Under $G+E_{x}$ and $G+E_{y}$ forces, $S 11$ Stresses in the Timurtaş (Demirtaş) Mosque $\left(\mathrm{KN} / \mathrm{m}^{2}\right)$.
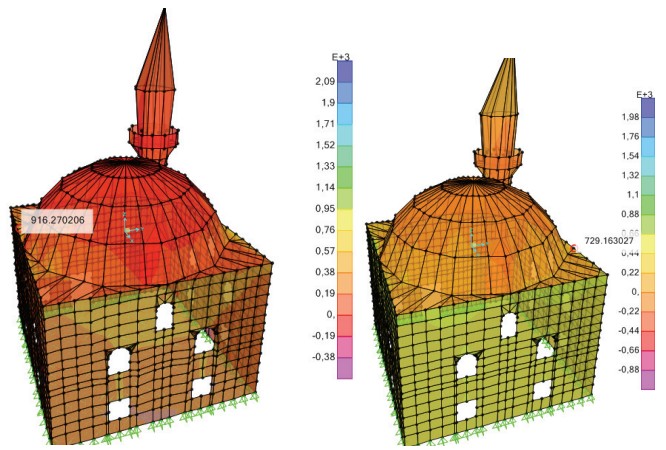

Fig. 14. Under $G+E_{x}$ and $G+E_{y}$ forces, $S 22$ Stresses in the Timurtaş (Demirtaş) Mosque $\left(\mathrm{KN} / \mathrm{m}^{2}\right)$.

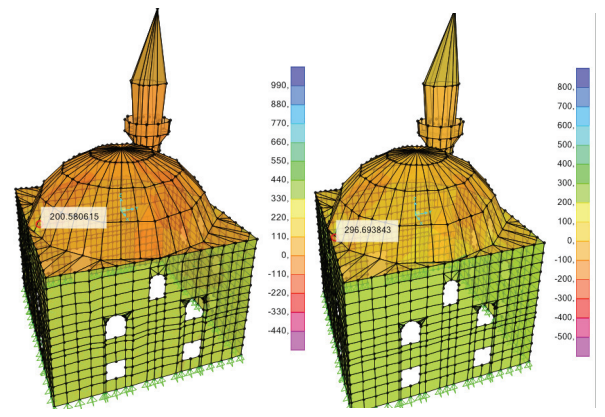

Fig. 15. Under $G+E_{x}$ and $G+E_{y}$ forces, $S 12$ Stresses in the Timurtaş (Demirtaş) Mosque $\left(\mathrm{KN} / \mathrm{m}^{2}\right)$.

\section{Conclusions}

From the early Ottoman architectural examples, they are historical structures covered by a squareshaped, single-volume dome. As a result of the analyzes, the following results were obtained.

- Timurtaş (Demirtas) Mosque: The maximum compressive stress at the construction is calculated as $1.1 \mathrm{MPa}$, which exceeds the pressure safety tensile strength of $0.3 \mathrm{MPa}$. The tensile stresses determined at $2.16 \mathrm{MPa}$ exceed the tensile safety stress and reinforcement is required. The calculated maximum displace stress was $0.99 \mathrm{MPa}$. This value exceeds the safe displace stress value is calculated as $0.175 \mathrm{MPa}$. As of January 2017, the current situation has been examined and it has been determined that there are spills and dissociations in 
the stones forming the body walls in particular. Despite the high stresses in the finished element model, there are no large and risky cracks in the areas where the cowbag merges with the body walls and in the window and door openings. This can be interpreted to mean that the structure still retains its stability. However, maintenance of the damaged stones and filling of the gap between the joints will be favorable for the continuation of the stable condition of the building. When the analysis results are evaluated, it is observed that there are great stresses in the walls forming the main building, in the dome, in the doors, in the window spaces and in the minaret. Especially for historic buildings built with materials that are inadequate for tensile strength, these high values of stress have a considerable risk. It is a necessity to improve these stresses if a child of the works studied in the study is thought to have collapsed the upper body walls of the dome without the dome before the restoration. Static problems that need to be solved with minimal intervention, while remaining faithful to historical structures, require the development of new methods. Otherwise, the historical buildings can not be kept up for a long time just by cleaning and repairing works.

\section{References}

1. A. H. Aköz, Deprem Etkisi Altindaki Tarihi Yiğma Yapilarin Onarim Ve Güçlendirilmesi, (2008)

2. N. Bayülke, Yiğma Yapilarin Deprem Davranişi Ve Güvenliği, 1.Türkiye Deprem Mühendisliği ve Sismoloji Konferansı, (2011)

3. Ö. Şişik, Edirne'de Bulunan 15.Yy Ve 16.Yy'da İnşaa Edilmiş Tarihi Cami Ve Türbelerin Taşıyıcı Sistem Analizi Ve Çözüm Önerileri, Konya, (2017)

4. M. Şahin, Eski yapıların korunmasında 'ICOMOS' ilkeleri, Bursa, (2015)

5. Türkiye Bina Deprem Yönetmeliği. DBYBHY2007, Türkiye, (2016)

6. S. Uğuz, Tarihi Yiğma Bir Binanin Deprem Güvenlik Analizi: Tarihi Konya-Gazi Lisesi (Darü'1 Muallim) Örneği, Konya (2016)

7. U.C.Yavuz, Tarihi Yapilarda Statik Güçlendirme Teknikleri, Ankara, Kültür ve Turizm Bakanlığı Kültür Varlıkları ve Müzeler Genel Müdürlüğü (2012) 